

\title{
BUKU AJAR \\ DESAIN GRAFIS SYNTAX DASAR HTML PADA \\ WEBSITE
}

\author{
Hijrah, M.Kom \\ Mukhlizar, M.Si \\ Heri Rahmatsyah Putra, M.Kom.I
}

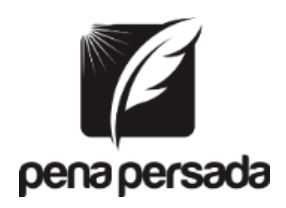

PENERBIT CV. PENA PERSADA 


\title{
BUKU AJAR \\ DESAIN GRAFIS SYNTAX DASAR HTML PADA WEBSITE
}

\author{
Penulis: \\ Hijrah, M.Kom \\ Mukhlizar, M.Si \\ Heri Rahmatsyah Putra, M.Kom.I \\ ISBN : 978-623-315-959-3 \\ Design Cover : \\ Retnani Nur Briliant \\ Layout : \\ Hasnah Aulia \\ Penerbit CV. Pena Persada \\ Redaksi : \\ Jl. Gerilya No. 292 Purwokerto Selatan, Kab. Banyumas \\ Jawa Tengah \\ Email : penerbit.penapersada@gmail.com \\ Website : penapersada.com Phone : (0281) 7771388

\section{Anggota IKAPI} \\ All right reserved \\ Cetakan pertama : 2022
}

Hak Cipta dilindungi oleh undang-undang. Dilarang memperbanyak karya tulis ini dalam bentuk apapun tanpa izin penerbit 


\section{KATA PENGANTAR}

\section{Ketua Sekolah Tinggi Agama Islam (STAIN) Teungku Dirundeng Meulaboh}

\section{Dr. Inayatillah, M.Ag}

Era digital telah menciptakan perubahan budaya virtual yang tidak terbendung dalam kehidupan sosial. Kemajuan teknologi informasi dan komunikasi menjadi inovasi yang harus didifusikan secara masiv kepada mahasiswa dan masyarakat secara umum. Hadirnya media baru berbasis digital menjadi tolak ukur kemajuan peradaban. Bagaimana tidak, melalui jaringan internet informasi dari segala penjuru dunia dapat dengan cepat dan mudah diakses melalui media digital saat ini. Internet sangat berkaitan dengan media website yang mampu menyajikan segala informasi yang dibutuhkan oleh penggunanya. Website yang dalam bahasa komunikasi dikenal dengan istilah World Wide Web (www) merupakan media komunikasi yang tersambung dengan jaringan internet dimana para penggunanya bisa menulis dan membaca atau mengakses semua informasi yang ada di dalamnya.

Kemajuan ini mengharuskan umat manusia untuk dapat beradaptasi terhadap gelombang perubahan tersebut. Mahasiswa sebagai generasi milenial harus mampu untuk mengimplementasikan segala kemajuan teknologi yang kini berada dalam genggaman. Tidak hanya sebagai pengguna maupun penikmat konten-konten yang disajikan. Mahasiswa Sekolah Tinggi Agama Islam Negeri (STAIN) Teungku Dirundeng Meulaboh diharapkan dapat mengambil bagian dalam perkembangan media komunikasi melalui pemahaman mengenai website. Tidak hanya sebagai pengguna, namun juga sebagai pengelola bahkan perancang sebuah website. Melalui buku ini diharapakan dapat menjadi acuan bagi mahasiswa STAIN Teungku Dirundeng Meulaboh dan masyarakat dalam menciptakan desain web yang menarik. 
Hal ini menjadi penting mengingat kompetensi lulusan khususnya pada program studi Komunikasi dan Penyiaran Islam agar dapat bersaing dan berkompetisi di tengah ketatnya persaingan dunia kerja di era industri 4.0. STAI Teungku Dirundeng Meulaboh tidak henti-hentinya mendorong dan memotivasi dosen-dosen yang ingin berkarir dan berkembang terutama dosen-dosen muda yang masih bersemangat, energi, serta kemampuan (hard skill dan soft skill) dan dapat bersaing dengan dosen-dosen di perguruan tinggi lainnya khususnya di PTKIN di lingkungan Kementerian Agama Republik Indonesia.

Dengan hadirnya buku ini, diharapkan dosen yang ada di ruang lingkup STAIN Teungku Dirundeng Meulaboh dapat terus berkarya dalam mengembangkan ilmu pengetahuan dan mampu memberikan kontribusi yang nyata bagi masyarakat sesuai dengan tri dharma perguruan tinggi.

Meulaboh, 5 Januari 2022

Ketua STAIN Teungku Dirundeng Meulaboh

Dr. Inayatillah, M.Ag 


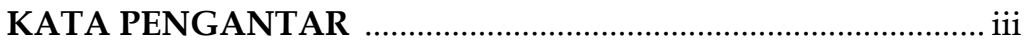





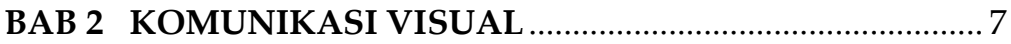



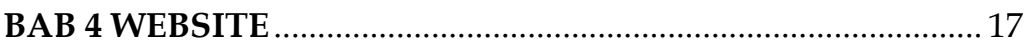

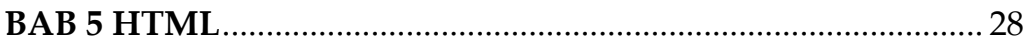

BAB 6 SINTAKS DASAR HTML …………………………..... 44

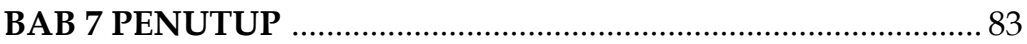

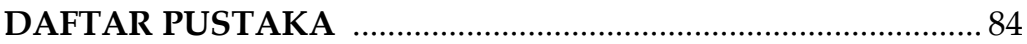




\section{BUKU AJAR \\ DESAIN GRAFIS SYNTAX DASAR HTML PADA WEBSITE}




\section{BAB 1 \\ PENDAHULUAN}

\section{A. Latar Belakang}

Dunia telah menghadapi perubahan dalam kurun waktu yang singkat, kemajuan peradaban umat manusia tidak terelakkan dari inovasi-inovasi yang terus bermunculan. Umat manusia terus berupaya dalam memaksimalkan hakikatnya sebagai makhluk hidup yang memiliki akal pikiran. Kemajuan peradaban manusia saat ini dapat diukur dari perkembangan teknologi komunikasi dan informasi yang semakin hari semakin canggih. Kehidupan manusia tidak akan lepas dari kebutuhan untuk berkomunikasi. Komunikasi merupakan setiap proses pertukaran informasi, gagasan, dan perasaan. Proses komunikasi meliputi informasi yang disampaikan, baik lisan maupun secara tertulis, dengan kata-kata, atau yang disampaikan dengan bahasa tubuh, gaya maupun penampilan diri, maupun menggunakan media (Putra, 2020).

Pada perkembangan awal, batasan komunikasi yang diterapkan adalah percakapan atau penyampaian gagasan antar manusia secara lisan dan bertatap muka baik berupa pidato maupun diskusi, dengan tujuan mendidik, membangkitkan kepercayaan, dan menggerakkan perasaan orang lain. Komunikasi terus berkembang, tidak hanya menyampaikan gagasan melalui lisan. Pada zaman kekaisaran romawi, Julius Caesar membuat papan pengumuman yang dinamakan Acta Diurna. Penyampaian gagasan mengenai apa yang penting bagi masyarakat telah bertambah, dari sekadar lisan menjadi bentuk tulisan. Hal ini terus berkembang setelah ditemukannya kertas, penemuan mesin cetak, dan terbitnya surat kabar pertama.

Sejarah mencatat terdapat beberapa tonggak perkembangan teknologi yang secara nyata memberi kontribusi terhadap perkembangan teknologi komunikasi informasi (TIK) hingga saat ini. Penemuan telepon oleh Alexander Graham Bell pada tahun 1875 yang kemudian berkembang menjadi 
pengadaan jaringan komunikasi dengan kabel yang meliputi seluruh daratan di Amerika, bahkan kemudian diikuti pemasangan kabel komunikasi trans-atlantik. Jaringan telepon ini merupakan infrastruktur masif pertama yang dibangun manusia untuk komunikasi global. Kehadiran telepon sebagai media transmisi pertama yang berhasil menggungguli efektivitas media cetak pada saat itu telah berhasil merubah tatanan peradaban manusia menjadi lebih cepat dan lebih akurat dalam penyaluran informasi. Media transmisi merupakan media yang dipakai untuk membawa informasi dari sender atau pengirim menuju ke receiver atau penerima.

Kemudian memasuki abad ke-20, tepatnya antara tahun 1910-1920, perkembangan TIK ditandai dengan sebuah transmisi suara tanpa kabel melalui siaran radio AM yang pertama. Komunikasi suara tanpa kabel ini pun segera berkembang pesat yang diikuti pula oleh transmisi audio-visual tanpa kabel, yang berwujud siaran televisi pada tahun 1940-an. Pada 1939, Dr. John V. Atanasoff dan dibantu oleh Clifford Berry berhasil menciptakan komputer elektronik digital pertama. Sejak saat ini, komputer terus mengalami perkembangan sehingga menjadi semakin canggih. Komputer elektronik juga sebagai wujud perkembangan TIK, beroperasi prtama kali pada tahun 1943. Lalu diikuti oleh tahapan miniaturisasi komponen elektronik melalui penemuan transistor pada tahun 1947 dan rangkaian terpadu (integrated electronics) pada tahun 1957.

Perkembangan teknologi elektronika, yang merupakan cikal bakal TIK saat ini, mendapatkan momen emasnya pada era Perang Dingin. Persaingan IPTEK antara blok Barat Amerika Serikat dan blok Timur Uni Soviet (sekarang Rusia) justru memacu perkembangan teknologi elektronika lewat upaya miniaturisasi rangkaian elektronik untuk pengendali pesawat ruang angkasa maupun mesin-mesin perang. Miniaturisasi komponen elektronik, melalui penciptaan rangkaian terpadu, pada puncaknya melahirkan mikroprosesor. Mikroprosesor inilah yang menjadi 'otak' perangkat keras komputer dan terus berevolusi sampai sekarang. 
Perangkat telekomunikasi berkembang pesat saat teknologi digital mulai digunakan menggantikan teknologi analog. Teknologi analog mulai terasa menampakkan batasbatas maksimal pengeksplorasiannya. Digitalisasi perangkat telekomunikasi kemudian berkonvergensi dengan perangkat komputer yang sejak awal merupakan perangkat yang mengadopsi teknologi digital. Produk hasil konvergensi inilah yang saat ini muncul dalam bentuk telepon seluler. Di atas infrastruktur telekomunikasi dan komputasi ini kandungan isi (content) berupa multimedia mendapatkan tempat yang tepat untuk berkembang. Konvergensi telekomunikasi-komputasi multimedia inilah yang menjadi ciri abad ke-21, sebagaimana abad ke-18 dicirikan oleh revolusi industri. Bila revolusi industri menjadikan berbagai jenis mesin sebagai pengganti 'otot' manusia, maka revolusi digital menciptakan mesin untuk mengganti (atau setidaknya meningkatkan kemampuan) 'otak' manusia.

Sebagai pengguna smartphone, internet, laptop dan sebagainya, umat manusia tentu telah dibuat cukup familiar dengan teknologi informasi dan komunikasi. Dalam perjalanannya, TIK menjadi payung besar terminologi yang mencakup seluruh peralatan teknis untuk memproses dan menyampaikan informasi. TIK sendiri mencakup dua aspek, yaitu teknologi informasi dan teknologi komunikasi. Teknologi informasi meliputi segala hal yang berkaitan dengan proses, penggunaan sebagai alat bantu, manipulasi, dan pengelolaan informasi. Sedangkan teknologi komunikasi adalah segala sesuatu yang berkaitan dengan penggunaan alat bantu untuk memproses dan mentransfer data dari perangkat yang satu ke lainnya. TIK muncul setelah adanya perpaduan antara teknologi komputer (baik perangkat keras maupun perangkat lunak) dengan teknologi komunikasi pada pertengahan abad ke-20.

Perpaduan kedua teknologi tersebut berkembang pesat melampaui bidang teknologi lainnya saat ini. Hingga awal abad ke-21, TIK masih terus mengalami berbagai perubahan dan belum terlihat titik jenuhnya. Perkembangan ilmu pengetahuan 
dari masa ke masa tak dimungkiri telah menimbulkan adanya perubahan yang signifikan pada perkembangan teknologi informasi dan komunikasi. Perkembangan ini turut berdampak kepada perubahan budaya yang sebelumnya ke arah budaya virtual. Segala aktivitas manusia kini sangat bergantung kepada media internet. Hal ini mengharuskan setiap individu untuk melek terhadap dunia internet.

Dalam sistem komputerisasi terdapat perangkat keras (hardwere) dan perangkat lunak (softwere). Hardware merupakan segala piranti atau komponen dari sebuah komputer yang sifatnya bisa dilihat secara kasat mata dan bisa diraba secara langsung. Rainer mendefinisikan hardware adalah perangkat dalam komputer yang berbentuk fisik seperti processor, monitor, keyboard, dan printer. Hardware berfungsi untuk menerima data/ informasi, memproses dan menampilkan informasi mentah menjadi informasi baru yang berguna. Sedangkan softwere ialah suatu himpunan dari beberapa perintah yang dilakukan oleh mesin komputer dalam melakukan berbagai tugasnya. Lebih lanjut, software adalah suatu perangkat lunak yang menjadi catatan untuk mesin komputer dalam menyimpan perintah dan berbagai dokumen ataupun arsip lainnya. Salah satu softwere yang penting dalam internet adalah website.

Website merupakan kumpulan laman web yang berada di server dan berisi informasi. Sedangkan laman web sendiri banyak diartikan sebagai sebuah halaman web yang menjadi antar muka dengan pengunjung. Kebanyakan saat ini orang mengartikan website sebagai web company profile yang menjadi sebuah identitas dari sebuah perusahaan tertentu. Pada penerapannya web tidak hanya digunakan untuk company profile, bisa juga web aplication atau aplikasi berbasis web yang lebih mengutamakan fungsionalitasnya pada suatu instansi untuk tujuan tertentu. Dalam perkembangan dunia digital, website telah menjadi sarana atau media dalam menyampaikan informasi. Website umumya telah digunakan pada setiap aktivitas penyebaran informasi oleh pemerintah, perusahaan, 
dan instansi lainnya yang memiliki kepentingan untuk berkomunikasi dengan pengguna atau masyarakat.

\section{B. Tujuan}

Website menjadi salah satu media baru yang dirasakan sangat efektif karena mudah diakses menggunakan perangkat yang terhubung dengan internet. Secara sederhana website digunakan untuk mengakses berita online sebagai pengganti dari media cetak yang memiliki kelemahan menyampaikan informasi karena sifatnya yang kurang update. Hingga saat ini, ledakan pengguna website tidak terbendung lagi karena dengan website masyarakat luas lebih update terhadap informasi. Tidak hanya itu, banyak perusahaan yang bergerak dalam penjualan barang dan jasa juga lebih memilih menggunakan website untuk mengiklankan produknya ketimbang menggunakan media cetak dan media elektronik.

Pemanfaatan website sebagai media komunikasi dan informasi suatu lembaga institusi saat ini sudah hampir sepenuhnya memadai. Karena selain biayanya yang murah daripada harus memasang iklan di media lain, website resmi lembaga juga dapat dikelola secara mandiri oleh institusi tersebut. Salah satu kelebihan pemanfaatan website yang mungkin tidak disadari oleh para pemilik usaha yang sedang berkembang ialah mampu meningkatkan kredibilitas perusahaan. Dengan kata lain, jika sebuah perusahaan memiliki website, maka sudah pasti hal ini akan memudahkan para konsumen untuk melakukan pencarian barang yang anda tawarkan kepada mereka. Selain itu, website juga memudahkan untuk menyampaikan feedback dari pengguna atau konsumen. Kelebihan dalam menaggapi testimoni yang disampaikan melalui website memudahkan perusahaan untuk mengevaluasi permintaan publik.

Kemudian sebab lain yang menegaskan pentingnya penggunaan website karena dalam sebuah website tentunya akan ada domain yang nantinya menjadi brand dari sebuah perusahaan ataupun bisnis yang sedang dijalankan. Dari adanya 
domain tersebut, terkait dengan kelebihan pembuatan website, setiap website memiliki domain yang berbeda sehingga hal ini bisa dijadikan sebagai media untuk self-branding atas perusahaan yang bersangkutan Banyak sekali kelebihan website sebagai media untuk mengembangkan usaha pada masa sekarang. Dengan kata lain, penggunaan website akan mendapatkan ragam keuntungan seperti halnya peningkatkan proteksi branding, mempermudah dalam promosi dan lain sebagainya. Oleh sebab itu memanfaatkan perkembangan teknologi dengan mengambil manfaat atas hadirnya website merupakan hal yang sangat penting di era digital.

Namun penggunaan website saat ini belum begitu memadai karena dalam merancang sebuah website belum semuanya efektif. Desain layout, penggunaan warna, bentuk, tulisan, dan bahasa yang disajikan di dalam sebuah laman web masih terdapat banyak kekurangan sehingga tidak menimbulkan ketertarikan dan kepuasan pada pengguna web tersebut. Kemampuan untuk merancang dan mengelola website saat ini menjadi sebuah potensi yang seharusnya dimiliki oleh generasi muda. Hal ini berdasarkan kepada kebutuhan dan ketergantungan umat manusia terhadap layanan informasi digital yang sangat tinggi. Hampir setiap menit berbagai laman web diakses di seluruh belahan dunia. Maka dari itu dibutuhkan referensi yang tepat untuk mempelajari proses pembuatan website yang menarik sehingga segala ramai dikunjungi dan penyebaran informasi menjadi lebih efektif. 


\section{BAB 2 \\ KOMUNIKASI VISUAL}

\section{A. Definsi Komunikasi Visual}

Istilah visual jika dirujuk pada maknanya adalah dapat dilihat dengan mata berdasarkan penglihatan. Sesuatu yang dapat dilihat atau dengan kata lain dapat dinikmati oleh indera penglihatan (Walisyah, 2009). Berarti mengandung makna bahwa sesuatu tersebut sama dengan gambar atau hal lain yang bisa ditangkap oleh mata. Visual (Visual Communication) adalah proses penyampaian informasi atau pesan menggunakan media penggambaran yang hanya terbaca oleh indra penglihatan. Bentuk komunikasi visual bisa bersifat langsung (menggunakan bahasa isyarat) dan menggunakan media perantara yang lazim disebut media komunikasi visual.

Komunikasi visual merupakan payung dari berbagai kegiatan komunikasi yang menggunakan unsur rupa (visual) pada berbagai media: percetakan/grafika, luar ruang (marka grafis, papan reklame), televisi, film/video, internet dan lainlain. Desain Grafis yang mengacu pada foto dan gambar juga temasuk bagian dari proses komunikasi visual. Konsep komunikasi visual adalah memadukan unsur-unsur desain grafis, seperti kreativitas, estetika, efisiensi, komunikatif dan sebagainya untuk menciptakan suatu media yang dapat menarik perhatian, juga menciptakan media komunikasi yang efektif agar diapresiasi oleh komunikan/audiens. Salah satu tujuan komunikasi visual ialah mengidentifikasi pesan melalui pengamatan terhadap pesan nonverbal, karena pada hakikatnya komunikasi visual menggunakan mata sebagai alat penglihatan merupakan komunikasi yang menggunakan bahasa visual dengan unsur dasarnya yang dilihat dan dipakai untuk menyampaikan arti, makna atau pesan (Kusrianto, 2009). 
Desain komunikasi visual merupakan ilmu yang mempelajari konsep komunikasi dan ungkapan daya kreatif, yang kemudian diaplikasikan dalam berbagai media komunikasi visual dengan mengolah elemen desain grafis yang terdiri dari gambar (ilustrasi), huruf, warna, komposisi dan layout. Hal ini dilakukan guna menyampaikan pesan secara audio, visual, dan audio visual kepada target yang dituju. Desain komunikasi visual menjadi salah satu bagian dari seni terapan yang mempelajari tentang perencanaan dan perancangan berbagai bentuk informasi komunikasi visual. Perjalanan kreatifnya diawali dari menemukan permasalahan komunikasi visual, mencari data verbal dan visual, menyusun konsep kreatif yang berlandaskan pada karakteristik target, sampai dengan penentuan visualisasi final desain untuk mendukung tercapainya sebuah komunikasi verbal-visual yang fungsional, persuasif, artistik, estetis, dan komunikatif. menurut Sumbo Tinarbuko, desain komunikasi visual dapat dipahami sebagai salah satu upaya pemecahan masalah (komunikasi, atau komunikasi visual) untuk menghasilkan suatu desain yang paling baru di antara desain yang baru.

Istilah desain komunikasi visual, dalam bahasa anak muda disebut 'dekave' yang digunakan untuk memperbaharui atau memperluas jangkauan cakupan ilmu dan wilayah kerja kreatif desain grafis. Dalam ranah desain komunikasi visual ini dipelajari semua bentuk komunikasi yang bersifat komunikasi visual seperti desain grafis, desain iklan, desain multimedia interaktif. Desain komunikasi visual sangat akrab dengan kehidupan manusia, karena merupakan representasi sosial budaya masyarakat, dan salah satu manifestasi kebudayaan yang berwujud produk dari nilai-nilai yang berlaku pada waktu tertentu. Serta menjadi kebudayaan yang benar-benar dihayati, bukan kebudayaan dalam arti sekumpulan sisa bentuk, warna, dan gerak masa lalu yang kini dikagumi sebagai benda asing terlepas dari diri manusia yang mengamatinya.

Andoko berpendapat bahwa "the real internet is not technology, it's about people communicating, people offering and 
searching for information". Tampilan atau produk dari sebuah internet adalah sebuah proses komunikasi yang disampaikan secara visual. Kerja seorang perancang atau desainer komunikasi visual berkaitan dengan informasi dan proses komunikasinya untuk dibaca oleh orang atau sekumpulan orang, termasuk didalamnya adalah usaha untuk mempengaruhi orang atau sekumpulan orang dengan kerja tersebut. Sebagai sebuah produk, desain web adalah hasil pemecahan masalah berdasarkan pendekatan komunikasi visual, berisi spesifikasi produk yang sangat khas dan operasional. Rancangan pada sebuah situs web adalah sebuah desain komunikasi visual yang ditayangkan melalui layar monitor yang dapat dihadirkan pada suatu waktu tertentu. Layar monitor berfungsi sebagai media komunikasi visual, tampilannya tidak ada bedanya dengan desain sebuah majalah atau surat kabar. Dengan demikian, dapat disimpulkan bahwa kaidah-kaidah pokok perancangan sebuah desain web merupakan kaidah-kaidah yang berkaitan dengan desain komunikasi visual (Freddy H. Istanto, 2001).

Jadi dapat dipahami bahwa website yang memiliki desain yang bagus akan menciptakan penyebaran informasi yang efektif kepada pengguna website. Hal ini disebabkan karena kekuatan komunikasi visual yang mampu menciptakan kesan estetik bagi komunikan (pengguna) website. Penyampaian informasi yang menyenangkan dengan tampilan desain web yang indah sangat berpengaruh terhadap respon atau feedback yang muncul. 


\section{BAB 3 \\ DESAIN GRAFIS}

\section{A. Definisi Desain Grafis}

Desain berasal dari bahasa Latin designare yang berarti membuat, membentuk, menandai, atau menunjuk. Kata 'desain' sendiri termasuk kepada kata baru yang dijadikan ke dalam bahasa Indonesia yang juga berasal dari bahasa Inggris 'design'. Namun dalam perkembangannya kata 'desain' menggeser makna kata 'rancang' karena kata tersebut tidak dapat mewadahi kegiatan, keilmuan, keluasan dan pamor profesi atau kompetensi Desainer (Sachari, 2000) sehingga desain diartikan merancang atau merencanakan. Lebih jelas Sachari dan Sunarya mengatakan bahwa desain adalah terjemahan fisik mengenai aspek sosial, ekonomi, dan tata hidup manusia, serta merupakan cerminan budaya zamannya. Desain adalah salah satu manifestasi kebudayaan yang berwujud, desain adalah produk dari nilai-nilai yang berlaku pada kurun waktu tertentu (Sachari, 2001). Maka dapat disimpulkan bahwa pengertian desain adalah perencanaan dan perancangan untuk membuat suatu benda, baik dari segi tampilan maupun fungsinya. Desain juga dapat berarti benda atau gambar/grafis hasil dari kegiatan desain itu sendiri.

Kata grafis sendiri mengandung dua pengertian, graphien yang berasal dari bahasa Latin memiliki arti garis, marka yang kemudian menjadi graphic arts atau komunikasi grafis, kemudia graphise vakken (Belanda) bermakna pekerjaan cetak, yang di Indonesia menjadi grafika, diartikan sebagai percetakan. Jadi desain grafis adalah pekerjaan dalam bidang komunikasi visual yang berhubungan dengan grafika (cetakan) dan/ atau pada bidang dua dimensi, dan statis (tidak bergerak dan bukan timebased image). Secara khusus, desain grafis adalah keahlian menyusun dan merancang unsur visual menjadi informasi yang dimengerti publik/masyarakat. 
Pada dasarnya desain grafis adalah suatu media untuk menyampaikan informasi melalui bahasa komunikasi visual dalam wujud dwimatra ataupun trimatra yang melibatkan kaidah-kaidah estetik. Bidang profesi desain grafis menangani konsep komunikasi grafis, merancang, dan meyelaraskan unsur yang ditampilkan dalam desain (huruf, gambar, dan atau foto, elemen grafis, warna) sesuai dengan tujuan komunikasi, dan mengawasi produksi (cetak). Dalam kerjanya, desainer grafis memberi brief dan pengarahan kepada ilustrator atau fotografer agar hasil yang diperoleh sesuai dengan rancangan desainnya.

Jadi, pengertian desain grafis adalah pekerjaan dalam bidang komunikasi visual yang berhubungan dengan grafika (cetakan) dan/ atau pada bidang dua dimensi, dan statis (tidak bergerak dan bukan time-based image). Secara khusus, desain grafis adalah keahlian menyusun dan merancang unsur visual menjadi informasi yang dimengerti publik/masyarakat. Bidang profesi desain grafis menangani konsep komunikasi grafis, merancang, dan meyelaraskan unsur yang ditampilkan dalam desain (huruf, gambar, dan atau foto, elemen grafis, warna) sesuai dengan tujuan komunikasi, dan mengawasi produksi (cetak). Dalam kerjanya, desainer grafis memberi brief dan pengarahan kepada ilustrator atau fotografer agar hasil yang diperoleh sesuai dengan rancangan desainnya.

Bidang profesi desain grafis meliputi kegiatan penunjang dalam kegiatan penerbitan (publishing house), media massa cetak koran dan majalah, dan biro grafis (graphic house, graphic boutique, production house). Selain itu, desain grafis juga menjadi penunjang pada industri nonkomunikasi (lembaga swasta/pemerintah, pariwisata, hotel, pabrik/manufaktur, usaha dagang) sebagai inhouse graphics di departemen promosi ataupun tenaga grafis pada departemen hubungan masyarakat perusahaan. 


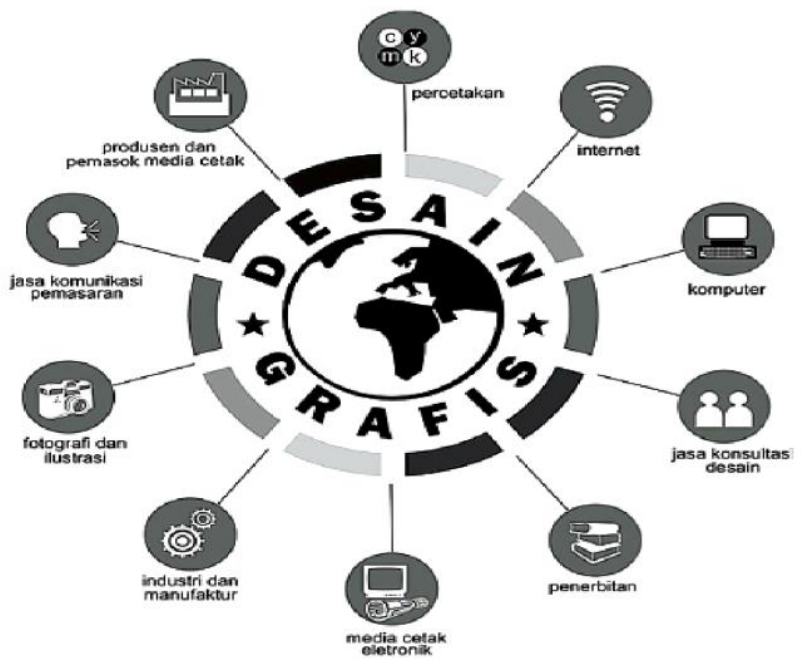

Gambar 1. Kaitan bidang desain grafis dengan bidang lainnya.

(Sumber: Penetapan SKKNI Sektor Komunikasi dan Informatika

Subsektor Teknologi dan Komunikasi Bidang Keahlian Desain Grafis).

\section{Infographic oleh: Ferry Wahyu)}

Bidang desain grafis merupakan bagian dari ilmu seni rupa yang dimanfaatkan untuk berkomunikasi. Karena itu, ada beberapa hal yang diprasyaratkan bagi yang akan bekerja dalam bidang profesi ini, antara lain menyangkut wawasan, keterampilan, kepekaan, dan kreativitas. Dalam buku FI9UR, Yongky Safanayong mengungkapkan "Desainer itu harus smart, tidak hanya strategi tetapi juga taktis." Dalam bidang kompetensi desain grafis hal yang harus dikuasai sebagai prakondisi sebelum bekerja adalah sebagai berikut.

1. Sikap Kerja (Attitude)

Bekerja sebagai penunjang bidang komunikasi membutuhkan manusia yang sadar akan tugasnya sebagai pengantar pesan/ informasi. Pada tingkat pemula, telah disadarkan akan tugas pentingnya aspek informatif. Pada jenjang yang lebih tinggi dibutuhkan wawasan mengenai teori komunikasi untuk melakukan tugas yang lebih rumit dalam olah visualnya. Hal tersebut menyangkut pertimbangan tentang.

a. Pesan/message (apa maksud informasi); 
b. Khalayak/audience (siapa masyarakat/pelihat yang dituju); dan

c. Sasaran/objective (apa yang diharapkan setelah mendapat informasi).

Kerumitan ketiga aspek ini akan berkembang sejalan dengan makin kompleksnya masalah komunikasi yang dihadapi.

2. Pengetahuan, Keterampilan, dan Kepekaan (Skill, knowledge and Sensibility)

Dalam bidang desain grafis, beberapa pengetahuan dasar kesenirupaan umum dan keterampilan/kepekaan khusus perlu diperoleh sebelum terjun ke lapangan kerja untuk menyamakan hal-hal sebagai berikut.

a. Pengetahuan, keterampilan, dan kepekaan olah unsur rupa/desain (garis, bidang, bentuk, tekstur, kontras, ruang, irama, warna, dan lain-lain) serta prinsip desain (harmoni, keseimbangan, irama, kontras, kedalaman, dan lain-lain). Untuk desain grafis disyaratkan penguasaan garida (grid system) dan kolom halaman;

b. Pengetahuan warna (lingkaran warna, intensitas, analog, saturasi, kromatik, dan lain-lain) dan kepekaan warna, baik aditif (cahaya langsung) maupun subtraktif (pantulan/pigmen), pengetahuan warna monitor $(R G B)$ dan warna untuk percetakan (CMYK, Spot Color);

c. Memiliki pengetahuan dan keterampilan dalam olah huruf/ tipografi: keluarga huruf, ukuran huruf, bobot huruf, istilah dalam tipografi, dan keterampilan mengolah huruf, baik secara manual (dengan tangan) maupun secara digital;

d. Memiliki keterampilan menggambar dan kepekaan pada unsur gambar (garis, bidang, warna, dan seterusnya);

e. Memiliki pengetahuan dasar fotografi.

3. Kreativitas (Creativity) 